\title{
Pengaruh Dosis Pupuk Guano dan NPK terhadap Pertumbuhan dan Produksi Tanaman Tomat (Lycopersicum esculentum Mill.)
}

\author{
The Effect of Guano Dossages and NPK Fertilizers on the Growth and Production of \\ Tomato (Lycopersicum esculentum Mill.)
}

\author{
Agus Maulidani $^{1}$, Jumini ${ }^{*}$, Trisda Kurniawan ${ }^{1}$ \\ ${ }^{1}$ Program Studi Agroteknologi, Fakultas Pertanian, Universitas Syiah Kuala
}

\begin{abstract}
Abstrak. Penelitian ini bertujuan untuk mengetahui pengaruh dosis pupuk guano dan NPK serta mengetahui nyata tidaknya interaksi antara keduanya terhadap pertumbuhan dan produksi tanaman tomat. Penelitian ini dilaksanakan di Gampong Lamdom, Lueng Bata, Banda Aceh, dari Januari sampai April 2018. Penelitian menggunakan Rancangan Acak Kelompok pola Faktorial dengan 12 perlakuan yang diulang sebanyak 3 kali. Penelitian ini terdiri dari 2 faktor yaitu dosis pupuk guano $0,4,8$, dan 12 ton ha ${ }^{-1}$ dan dosis pupuk NPK 0,250 , dan $500 \mathrm{~kg} \mathrm{ha}^{-1}$. Kombinasi yang terbaik terhadap pertumbuhan dan produksi tanaman tomat dijumpai pada perlakuan dosis pupuk guano 12 ton ha ${ }^{-1}$ dengan NPK $250 \mathrm{~kg} \mathrm{ha}^{-1}$.
\end{abstract}

Kata kunci : Tomat, Pupuk Guano, NPK.

Abstrack. This research was conducted to know the effect of guano dossages and NPK fertilizers and interaction between them on growth and production of tomato. This research was conducted at Lamdom village, Lueng Bata, Banda Aceh, from Januari to April 2018. The research was using factorial randomized block design with 12 repeated 3 times treatments. This research consisted of 2 factors namely dosage of guano fertilizer 0,4 , 8,12 ton ha ${ }^{-1}$ and dossages of NPK 0,250 , and $500 \mathrm{~kg} \mathrm{ha}^{-1}$. The best combination on the growt and production of tomato was found in the treatment of dosages guano of 12 ton ha $^{-1}$ with NPK $250 \mathrm{~kg} \mathrm{ha}^{-1}$.

Keywords: Tomato, Guano Fertilizer, NPK.

\section{PENDAHULUAN}

Tanaman tomat (Lycopersicum esculentum Mill.) merupakan tanaman yang banyak diminati dikarenakan mempunyai rasa asam dan manis. Tomat juga banyak digunakan hampir disemua masakan, bahan baku industri makanan dan kosmetik. Tomat juga bisa dimanfaatkan sebagai obat-obatan karena mengandung gizi yang lengkap dan bermanfaat buat kesehatan. Buah tomat bermanfaat untuk mencegah penyakit kanker, seperti kanker prostat (Maryanto dan Rahmi, 2015).

Permintaan pasar terhadap komoditas tomat dari tahun ke tahun semakin meningkat, akan tetapi produksi tanaman tomat tidak terjadi peningkatan secara signifikan, yang disebabkan oleh beberapa kendala yang dialami dalam budidaya tanaman tomat, seperti hama dan penyakit sulit dikendalikan, keadaan tanah, hingga pemasaran hasil panen. Saat ini para petani banyak menggunakan bahan kimia seperti pupuk, pestisida dan lain-lain sebagai penyelesaian dari sebagian masalah tersebut. Pada dasarnya penggunaan bahan kimia secara berlebihan pada budidaya tanaman dapat menimbulkan kerusakan bagi lingkungan, mulai dari pencemaran air, tanah, dan juga membunuh mikroorganisme yang bermanfaat, yang akan berefek kepada produktifitas tomat. Oleh karena itu, alternatif yang dapat dilakukan untuk menyelesaikan masalah tersebut adalah penggunaan bahan organik yaitu penggunaan pupuk guano dan juga mulsa organik yang akan meningkatkan produktifitas tomat secara berkelanjutan tanpa merusak lingkungan (Sulkarnain, 1990).

Kesuburan dan kecukupan unsur hara dalam tanah merupakan aspek yang penting bagi kelangsungan hidup tanaman. Unsur hara tersedia didalam tanah, akan tetapi bahan organik tanah lebih bermuatan negatif, maka unsur hara didalam tanah tersedia dalam bentuk anion, 
sehingga akan mudah tercuci oleh air yang menyebabkan unsur hara tersebut tidak tersedia bagi tanaman. Nitrogen memang tersedia dalam bentuk kation (amonium), akan tetapi bentuk tersebut akan segera teroksidasi menjadi anion (nitrat) oleh bakteri yang ada didalam tanah (Lakitan, 2007). Oleh karena itu, penggunaan pupuk organik seperti pupuk guano perlu dilakukan untuk memperbaiki sifat tanah. Penggunaan pupuk guano dapat memperbaiki tata air, udara, dan keseimbangan hara didalam tanah.

Menurut Rachman et al. (2008) fungsi bahan organik adalah untuk memperbaiki sifat fisik, kimia, dan biologi tanah. Menurut penelitian Djuniwati et al. (2003) dan Banuwa et al. (2003) pemberian bahan organik dapat memperbaiki pH tanah, meningkatkan Unsur NPK tersedia di dalam tanah, kadar dan serapan hara N, P, dan K tanaman, dan meningkatkan produktivitas tanaman.

Guano merupakan sumber pupuk organik yang baik untuk diberikan terhadap tanaman budidaya. Guano memiliki kandungan mineral mikro dan makro yang lengkap, dan pupuk guano juga memiliki unsur hara NPK yang tinggi. Hal inilah yang menjadi alasan dalam memanfaatkan pupuk guano sebagai pupuk organik untuk mencukupi unsur hara didalam tanah (Licardo, 2016). Hasil penelitian Sarawa dan Dasril (2012) menyimpulkan bahwa pemberian pupuk guano 12 ton $\mathrm{ha}^{-1}$ dengan mulsa alang-alang 15 ton ha ${ }^{-1}$ memberikan pengaruh tertinggi terhadap pertumbuhan maupun produksi tanaman kedelai $\left(3,70\right.$ ton $\left.\mathrm{ha}^{-1}\right)$. Hasil penelitian Taek (2016) menyimpulkan bahwa pemberian pupuk guano dengan dosis 5 ton/ha dan biochar 5 ton/ha mempunyai hasil tertinggi pada pertumbuhan dan produksi tanaman kacang hijau dibandingkan dengan perlakuan lain.

Pupuk guano mengandung unsur $\mathrm{N}$ yang tinggi yaitu $13 \%$ seperti yang dinyatakan oleh Lingga dan Marsono (2004), bahwa pupuk guano mengandung unsur hara yang penting bagi tanaman yaitu : $13 \% \mathrm{~N} ; 12 \% \mathrm{P}, 2 \% \mathrm{~K}, 11 \% \mathrm{Ca}, 1 \% \mathrm{Mg}$, dan $5 \% \mathrm{~S}$. Unsur $\mathrm{N}$ berpengaruh terhadap pertumbuhan vegetatif tanaman. Dikarenakan unsur $\mathrm{N}$ sangat dibutuhkan untuk pembentukan klorofil, sintesis asam amino, protein dan asam nukleat (Nugrahini, 2013). Kandungan unsur N, P, K pupuk guano lebih tinggi yaitu 8-13\% N, 5$12 \% \mathrm{P}$, dan 1,5-2\% K, dari pada pupuk kandang kotoran sapi yaitu 1,23\% N, 0,55\% P, 0,69\% $\mathrm{K}$ dan pupuk kandang kotoran ayam yaitu 3,77\% N, 1,89\% P dan 1,76\% K (Suwarno dan Idris, 2007). Hal ini menunjukkan bahwa pupuk guano lebih unggul dalam hal kandungan unsur hara dari pada pupuk kandang lainnya, sehingga diharapkan dengan menggunakan pupuk guano dapat meminimalisir penggunaan pupuk buatan (anorganik).

Pupuk guano mengandung unsur hara yang dibutuhkan oleh tanaman, akan tetapi perlu terjadi nya penguraian dalam waktu yang lama agar unsur hara tersebut bisa digunakan oleh tanaman. Namun pada fase vegetatif tanaman memerlukan unsur hara yang cukup dan langsung tersedia untuk pertumbuhannya. Oleh karena itu, penggunaan pupuk anorganik perlu dilakukan untuk mencukupi unsur hara didalam tanah dikarenakan unsu hara didalam pupuk anorganik cepat diserap oleh tanaman. Pupuk majemuk seperti pupuk NPK mutiara 16-16-16 sering digunakan sebagai altenatif guna mengurangi biaya pupuk tunggal. Beberapa kelebihan dari pupuk anorganik NPK adalah praktis dalam pemakaian, mudah didapat, minim ongkos angkutan, dan dapat disimpan lama (Yulipriyanto, 2010).

Penggunaan pupuk NPK yang dianjurkan untuk tanaman tomat adalah sebanyak 250 $\mathrm{kg} / \mathrm{ha}$ (Wudianto, 2001). Menurut penelitian Hendri et al. (2015) tanaman terong tertinggi terdapat pada perlakuan $200 \mathrm{~kg} / \mathrm{ha}$ yaitu $5,69 \mathrm{~cm}, 14,48 \mathrm{~cm}, 32,75 \mathrm{~cm}$, dan berat buah pertanaman yaitu 1587,78 g. Sedangkan pada penelitian Saberan et al. (2014) menyatakan bahwa buah tomat terberat (195,83 g/tanaman dijumpai pada pemberian pupuk NPK $375 \mathrm{~kg}$ $\mathrm{ha}^{-1}$ atau $3,75 \mathrm{~g} /$ polibag sedangkan yang paling rendah (120,83 g/tanaman) dihasilkan pada perlakuan tanpa pupuk NPK Pelangi. 
Jika tanaman kekurangan akan usnur hara, maka proses metabolisme seperti pertumbuhan akar, batang, daun akan terganggu. Bahkan sebaliknya, kelebihan unsur hara juga dapat menyebabkan keracunan bagi tanaman (Lakitan, 2007).

Tujuan penelitian ini adalah untuk mengetahui pengaruh dosis pupuk guano, NPK, dan nyata tidaknya interaksi antara keduanya terhadap pertumbuhan dan produksi tanaman tomat.

\section{METODE PENELITIAN}

Penelitian ini dilakukan di Lamdom, Kecamatan Lueng Bata, Banda Aceh pada Januari sampai April 2018, dengan menggunakan rancangan acak kelompok pola faktorial $4 \mathrm{x}$ 3 dengan 3 ulangan. Ada 2 faktor yang diteliti yaitu dosis pupuk guano terdiri dari 4 taraf yaitu $0,4,8$, dan12 ton $\mathrm{ha}^{-1}$, dan dosis NPK terdiri dari 3 taraf yaitu 0,250 , dan $500 \mathrm{~kg} \mathrm{ha}^{-1}$. Secara keseluruhan terdapat 12 kombinasi perlakuan.

\section{HASIL DAN PEMBAHASAN}

\section{Interaksi}

Interaksi antara dosis pupuk guano dengan NPK terhadap pertumbuhan dan produksi tanaman tomat dapat dilihat pada Tabel 1.

Tabel 1. Interaksi dosis pupuk guano dengan NPK terhadap pertumbuhan dan produksi tanaman tomat

\begin{tabular}{|c|c|c|c|c|}
\hline \multirow{2}{*}{ Parameter } & \multirow{2}{*}{$\begin{array}{c}\text { Dosis pupuk Guano } \\
\left(\text { ton } \text { ha }^{-1}\right)\end{array}$} & \multicolumn{3}{|c|}{ Dosis pupuk NPK $\left(\mathrm{kg} \mathrm{ha}^{-1}\right)$} \\
\hline & & $\mathbf{0}$ & 250 & 500 \\
\hline \multirow{4}{*}{$\begin{array}{c}\text { Tinggi tanaman } 30 \\
\text { HSPT }(\mathrm{cm})\end{array}$} & 0 & $26,33 \mathrm{a}$ & $24,67 \mathrm{a}$ & $30,33 \mathrm{ab}$ \\
\hline & 4 & $25,67 \mathrm{a}$ & $28,00 \mathrm{a}$ & $33,67 \mathrm{abc}$ \\
\hline & 8 & $31,33 \mathrm{ab}$ & $39,67 \mathrm{bc}$ & $42,33 \mathrm{c}$ \\
\hline & 12 & $57,67 \mathrm{de}$ & $64,33 \mathrm{e}$ & $53,67 \mathrm{~d}$ \\
\hline \multicolumn{2}{|c|}{ BNJ } & \multicolumn{3}{|c|}{10,07} \\
\hline \multirow{4}{*}{$\begin{array}{l}\text { Berat buah tomat } \\
\qquad(\mathrm{g})\end{array}$} & 0 & $127,19 \mathrm{a}$ & $183,17 \mathrm{ab}$ & $213,60 \mathrm{ab}$ \\
\hline & 4 & $220,52 \mathrm{ab}$ & $222,47 \mathrm{ab}$ & $280,65 \mathrm{~b}$ \\
\hline & 8 & $446,83 \mathrm{c}$ & $452,01 \mathrm{c}$ & $414,43 \mathrm{c}$ \\
\hline & 12 & $671,87 \mathrm{~d}$ & $823,40 \mathrm{e}$ & $573,42 \mathrm{~d}$ \\
\hline \multicolumn{2}{|c|}{ BNJ } & \multicolumn{3}{|c|}{109,95} \\
\hline \multirow{4}{*}{$\begin{array}{l}\text { Jumlah buah } \\
\text { pertanaman }\end{array}$} & 0 & $3,33 \mathrm{a}$ & $4,00 \mathrm{a}$ & $5,33 \mathrm{ab}$ \\
\hline & 4 & $6,67 \mathrm{abc}$ & $5,67 \mathrm{ab}$ & $8,33 \mathrm{bcd}$ \\
\hline & 8 & 11,67 def & 9,33 cde & $12,00 \mathrm{ef}$ \\
\hline & 12 & $15,67 \mathrm{~g}$ & $22,00 \mathrm{~h}$ & $14,33 \mathrm{fg}$ \\
\hline \multicolumn{2}{|c|}{ BNJ } & \multicolumn{3}{|c|}{3,61} \\
\hline \multirow{4}{*}{$\begin{array}{l}\text { Jumlah tandan } \\
\text { pertanaman }\end{array}$} & 0 & $1,00 \mathrm{a}$ & $1,33 \mathrm{a}$ & $0,58 \mathrm{a}$ \\
\hline & 4 & $2,33 \mathrm{abc}$ & $2,00 \mathrm{ab}$ & 2,67 abcd \\
\hline & 8 & 3,33 bcde & $2,67 \mathrm{abcd}$ & 3,67 cde \\
\hline & 12 & $4,33 \mathrm{e}$ & $6,00 \mathrm{f}$ & $4,00 \mathrm{de}$ \\
\hline
\end{tabular}

BNJ

$\mathbf{1 , 6 0}$

Keterangan : Angka yang diikuti oleh huruf yang sama berbeda tidak nyata pada taraf $5 \%$ (Uji BNJ ${ }_{0,05}$ ). 
Tabel 1 dapat dilihat bahwa kombinasi perlakuan terbaik terhadap berat buah pertanaman diperoleh pada dosis pupuk Guano 12 ton ha $^{-1}$ dengan NPK $250 \mathrm{~kg} \mathrm{ha}^{-1}$, hal ini dikarenakan bahwa pada parameter jumlah buah pertanaman dan jumlah tandan pertanaman yang terbanyak juga diperoleh pada kombinasi tersebut, yang mana dari parameter perlakuan tersebut berkaitan dengan tinggi tanaman umur 30 HSPT, yang juga diperoleh pada kombinasi pupuk guano 12 ton ha ${ }^{-1}$ dengan NPK $250 \mathrm{~kg} \mathrm{ha}^{-1}$. Hal ini diduga bahwa pemberian pupuk guano 12 ton ha ${ }^{-1}$ dengan NPK $250 \mathrm{~kg} \mathrm{ha}^{-1}$ dapat memperbaiki beberapa sifat tanah sehingga akan memberikan respon yang maksimal pada tanaman tomat. Kombinasi dosis pupuk guano dengan NPK yang sesuai dapat memberikan respon yang maksimal terhadap pertumbuhan dan produksi tanaman tomat. Menurut Putri (2016), pemupukan yang ideal adalah apabila unsur hara yang diberikan sesuai dengan yang dibutuhkan tanaman. Sehingga unsur hara yang mencukupi tersebut dapat memberikan hasil yang maksimal terhadap pertumbuhan dan produksi tanaman tomat.

Pertumbuhan dan produksi tanaman tomat yang terendah dijumpai pada perlakuan tanpa pemupukan baik guano maupun NPK, kecuali pada parameter tinggi tanaman umur tanaman 30 HSPT yang terendah dijumpai pada perlakuan dosis pupuk guano 0 ton ha ${ }^{-1}\left(\mathrm{G}_{0}\right)$ dan NPK $250 \mathrm{~kg} \mathrm{ha}^{-1}\left(\mathrm{P}_{1}\right)$. Hal ini diduga unsur hara dibutuhkan tanaman untuk menunjang pertumbuhannya, baik itu pupuk organik maupun pupuk anorganik, akan tetapi pemberian pupuk organik lebih penting dibandingkan dengan yang hanya diberi pupuk anorganik, dikarenakan pupuk organik dapat memperbaiki sifat biologi, kimia dan fisika tanah. Dalam penelitian Wawan et al. (2006) menyebutkan bahwa pemberian pupuk guano memberikan respon yang lebih baik dibandingkan dengan yang hanya diberi pupuk dasar tanpa pupuk guano terhadap pertumbuhan tumpang sari tanaman kedelai dan sorgum. Pemberian pupuk NPK yang berlebihan pun akan menyebabkan keracunan terhadap tanaman tomat.

\section{Pengaruh Faktor Tunggal}

Pengaruh Dosis Pupuk NPK Terhadap Pertumbuhan dan Produksi Tanaman Tomat

Rata-rata pertumbuhan dan produksi tanaman tomat akibat perbedaan dosis pupuk NPK setelah di uji dengan BNJ 5\% dapat dilihat pada Tabel 2.

Tabel 2. Rata-rata pertumbuhan dan produksi tanaman tomat akibat perbedaan dosis pupuk NPK

\begin{tabular}{|c|c|c|c|c|}
\hline \multirow{2}{*}{ Parameter } & \multicolumn{3}{|c|}{ Dosis Pupuk NPK kg ha ${ }^{-1}$} & \multirow{2}{*}{$\begin{array}{l}\text { BNJ } \\
0,05\end{array}$} \\
\hline & 0 & 250 & 500 & \\
\hline \multicolumn{5}{|l|}{ Tinggi tanaman (cm) } \\
\hline 15 HSPT & 22,33 & 22,83 & 24,42 & - \\
\hline 45 HSPT & $52,56 \mathrm{a}$ & $60,58 \mathrm{a}$ & $66,08 \mathrm{~b}$ & 5,33 \\
\hline \multicolumn{5}{|l|}{ Diameter batang (cm) } \\
\hline $15 \mathrm{HSPT}$ & 0,45 & 0,48 & 0,45 & - \\
\hline 30 HSPT & 0,52 & 0,56 & 0,52 & - \\
\hline 45 HSPT & $0,61 \mathrm{a}$ & $0,69 \mathrm{~b}$ & $0,67 \mathrm{ab}$ & 0,07 \\
\hline Diameter buah (cm) & $3,62 \mathrm{a}$ & $4,11 \mathrm{~b}$ & $3,63 \mathrm{a}$ & 0,37 \\
\hline Jumlah buah pertandan & 3,58 & 3,58 & 3,75 & - \\
\hline
\end{tabular}

Tabel 2 menunjukkan bahwa diameter buah tomat terbesar diperoleh pada dosis NPK $250 \mathrm{~kg} \mathrm{ha}^{-1}$, hal ini dikarenakan bahwa pada jumlah buah pertandan yang paling banyak juga pada dosis tersebut, yang mana dari parameter perlakuan tersebut berkaitan dengan diameter 
pangkal batang 15, 30, dan 45 HSPT, yang juga diperoleh pada dosis NPK $250 \mathrm{~kg} \mathrm{ha}^{-1}$, Kecuali pada tinggi tanaman 15 dan 45 HSPT yang terbaik diperoleh pada dosis NPK $500 \mathrm{~kg}$ $\mathrm{ha}^{-1}$. Hal ini diduga bahwa dosis pupuk NPK $250 \mathrm{~kg} \mathrm{ha}^{-1}$ adalah dosis yang optimal sehingga akan menunjang pertumbuhan dan produksi tanamana tomat. Sesuai dengan penelitian Fuadi (2016) bahwa pertumbuhan dan produksi tanaman cabai merah tertinggi dijumpai pada pemberian pupuk NPK $250 \mathrm{~kg} \mathrm{ha}^{-1}$ memberikan hasil tertinggi terhadap pertumbuhan dan produksi tanaman cabai merah. Menurut Kallie (1993) kekurangan atau kelebihan unsur hara akan menyebabkan kemunduran pertumbuhan dan produksi tanaman secara keseluruhan. Menurut Sufardi (2012) jika kelebihan suatu unsur hara, maka tanaman akan memperlihatkan gejala yang disebut dengan gejala keracunan.

Pupuk NPK dapat memberikan kebutuhan unsur hara makro tambahan pada tanaman tomat, unsur $\mathrm{N}$ berfungsi untuk masa pertumbuhan vegetatif yaitu pembentukan batang dan daun. Unsur hara $\mathrm{P}$ berfungsi untuk masa pertumbuhan generatif tanaman yaitu merangsang bunga, pembentukan buah, meningkatkan kualitas biji dan merangsang perakaran dan unsur hara $\mathrm{K}$ berfungsi dalam fotosintesis, pembentukan protein dan pengangkutan karbohidrat (Sufardi, 2012). Pemberian pupuk NPK yang ideal terhadap tanaman tomat akan memberikan respon yang maksimal baik bagi pertumbuhan maupun produksi dari tanaman tersebut.

\section{Pengaruh Dosis Pupuk Guano Terhadap Pertumbuhan dan Produksi Tanaman Tomat}

Rata-rata pertumbuhan dan produksi tanaman tomat akibat perbedaan dosis pupuk guano setelah di uji dengan BNJ 5\% dapat dilihat pada Tabel 3.

Tabel 3. Rata-rata pertumbuhan dan produksi tanaman tomat akibat perbedaan dosis pupuk guano

\begin{tabular}{|c|c|c|c|c|c|}
\hline \multirow{2}{*}{ Parameter } & \multicolumn{4}{|c|}{ Dosis Pupuk Guano ton $\mathrm{ha}^{-1}$} & \multirow{2}{*}{$\begin{array}{l}\text { BNJ } \\
0,05\end{array}$} \\
\hline & 0 & 4 & 8 & 12 & \\
\hline \multicolumn{6}{|l|}{ Tinggi tanaman $(\mathrm{cm})$} \\
\hline 15 HSPT & $19,89 \mathrm{a}$ & $18,11 \mathrm{a}$ & $22,33 \mathrm{a}$ & $32,44 \mathrm{~b}$ & 4,64 \\
\hline 45 HSPT & $52,56 \mathrm{a}$ & $52,33 \mathrm{a}$ & $61,67 \mathrm{~b}$ & $80,22 \mathrm{c}$ & 6,8 \\
\hline \multicolumn{6}{|l|}{ Diameter batang (cm) } \\
\hline $15 \mathrm{HSPT}$ & $0,38 \mathrm{a}$ & $0,42 \mathrm{ab}$ & $0,47 \mathrm{~b}$ & $0,57 \mathrm{c}$ & 0,07 \\
\hline 30 HSPT & $0,44 \mathrm{a}$ & $0,48 \mathrm{ab}$ & $0,58 \mathrm{~b}$ & $0,68 \mathrm{c}$ & 0,08 \\
\hline $45 \mathrm{HSPT}$ & $0,53 \mathrm{a}$ & $0,60 \mathrm{a}$ & $0,68 \mathrm{~b}$ & $0,81 \mathrm{c}$ & 0,09 \\
\hline Diameter buah $(\mathrm{cm})$ & $4,08 \mathrm{~b}$ & $3,46 \mathrm{a}$ & $3,74 \mathrm{a}$ & $3,87 \mathrm{ab}$ & 0,47 \\
\hline Jumlah buah pertandan & $3,44 \mathrm{a}$ & $3,33 \mathrm{a}$ & $3,67 \mathrm{ab}$ & $4,11 \mathrm{~b}$ & 0,68 \\
\hline
\end{tabular}

Keterangan : Angka yang diikuti oleh huruf yang sama pada baris yang sama berbeda tidak nyata pada taraf $5 \%$ $\left(\mathrm{Uji} \mathrm{BNJ}_{0,05}\right)$.

Tabel 3 menunjukkan bahwa diameter buah terbesar diperoleh pada dosis tanpa pupuk guano, yang berbanding terbalik dengan parameter jumlah tandan pertanaman. Hal ini diduga karena jumlah buah pertanaman pada perlakuan tanpa pemupukan guano yang sedikit, sehingga tidak terjadinya perebutan unsur hara, yang menyebabkan ukuran buah yang seragam. Sedangkan pada perlakuan dosis pupuk guano lainnya memiliki jumlah buah yang lebih banyak, namun ukurannya bervariasi. Pada saat berlangsungnya penelitian juga terjadi musim kemarau sehingga menyebabkan terjadinya kegagalan penyerbukan dan kerontokan bunga yang berefek terhadap jumlah buah tomat yang sedikit. Sebagaimana dinyatakan oleh Kallie (1993) suhu tinggi akan menyebabkan serbuk sari sulit berkecambah, sehingga akan menyebabkan keguguran bunga. 
Parameter jumlah buah pertandan yang paling banyak diperoleh pada dosis pupuk guano 12 ton $\mathrm{ha}^{-1}$,yang mana dari parameter perlakuan tersebut berkaitan dengan tinggi tanaman dan diameter pangkal batang, yang juga diperoleh pada dosis 12 ton ha $^{-1}$. Hal ini diduga bahwa kadar unsur hara didalam pupuk guano (organik) relatif lebih rendah dibandingkan dengan kadar unsur hara dari pupuk anorganik. Oleh karena itu pemberian unsur hara organik dengan dosis yang lebih tinggi berpengaruh terhadap ketersediaan unsur hara didalam tanah yang pada awalnya memiliki kadar yang relatif rendah. Hasil penelitian Sarawa et al. (2012) produksi tanaman kedelai tertinggi dijumpai pada pemberian pupuk guano 12 ton $\mathrm{ha}^{-1}$. Dengan meningkatkan ketersediaan hara pada tanah yang diberikan pupuk guano dan mulsa sebagai akibat dari mineralisasi bahan organik oleh mikroba pengurai sehingga melepaskan sejumlah unsur hara yang dapat diserap oleh akar tanaman. Unsur hara yang diserap oleh tanaman sebagian berfungsi untuk menyusun senyawa organik.

Diameter buah tomat yang terbaik dijumpai pada perlakuan tanpa pemupukan guano.

Pupuk guano mengandung unsur $\mathrm{P}$ yang lebih tinggi dibandingkan dengan pupuk organik lainnya. Menurut penelitian Suwarno dan Idris (2007) bahwa pupuk guano mengandung unsur hara yaitu $13 \% \mathrm{~N}, 12 \% \mathrm{P}$, dan $-2 \% \mathrm{~K}$, pupuk kandang kotoran sapi yaitu $1,23 \% \mathrm{~N}, 0,55 \% \mathrm{P}, 0,69 \% \mathrm{~K}$ dan pupuk kandang kotoran ayam yaitu 3,77\% N, 1,89\% $\mathrm{P}$ dan $1,76 \% \mathrm{~K}$. Menurut Lingga dan Marsono (2004) bahwa kandungan pupuk guano yaitu : 13\% $\mathrm{N} ; 12 \% \mathrm{P}, 2 \% \mathrm{~K}, 11 \% \mathrm{Ca}, 1 \% \mathrm{Mg}$; dan $3,5 \% \mathrm{~S}$.

Pemberian pupuk guano sangat baik untuk memperbaiki kesuburan tanah secara berkelanjutan. Menurut Sufardi (2012) pupuk organik dapat memperbaiki sifat fisik, biologi tanah. Bahan organik digunakan sebagai bahan makanan bagi mikroba sehingga dapat menunjang aktifitasnya dalam menyediakan unsur hara.

Pemberian pupuk guano yang tinggi juga dapat memperbaiki struktur tanah sehingga pori-pori tanah menjadi lebih besar sehingga aerasi tanah menjadi lebih baik. Menurut Sufardi (2012) pupuk organik berperan mengubah butiran primer menjadi sekunder dalam pembentukan pupuk sehingga penyimpanan, penyediaan air, aerasi tanah, dan suhu tanah akan lebih baik. Pupuk organik berfungsi juga dalam penyediaan unsur hara didalam tanah. Meskipun unsur hara yang terkandung di dalam pupuk organik sedikit akan tetapi lengkap.

Suhu udara pada saat penelitian tergolong tinggi khususnya pada fase pembungaan sehingga parameter berat buah pertanaman, diameter buah, jumlah buah pertandan dan jumlah buah pertanaman tidak optimal yang menyebabkan hasil yang tidak sesuai dengan deskripsi dari tomat Lentana F1. Seperti yang dikemukakan oleh Wiryanta (2004), pertumbuhan dan produksi tanaman tomat juga dipengaruhi oleh faktor suhu yang sangat berpengaruh pada proses fisiologi. Suhu antara $24-28^{\circ} \mathrm{C}$ adalah suhu yang ideal terhadap pertumbuhan dan produksi tanaman tomat. Sementara untuk proses pembungaan tanaman tomat memerlukan temperatur malam hari sekitar $15-20^{\circ} \mathrm{C}$. Menurut Kallie (1993) suhu yang optimal berperan dalam penyerbukan dan perkecambahan serbuk sari, apabila suhu tidak sesuai dengan yang dibutuhkan maka serbuk sari sulit berkecambah, sehingga bunga akan menyebabkan keguguran.

Menurut Rubatzky dan Yamaguchi (1999) periode pembentukan buah yang paling peka terhadap suhu adalah pada saat 5-10 hari sebelum bunga mekar, dan 2-3 hari setelah bunga mekar. Suhu tinggi berkepanjangan akan mengakibatkan buah dan bunga tanaman tomat mengalami gangguan sehingga buah dan bunga akan layu, mengerut, dan kemudian akan rontok (Kallie, 1993). 


\section{KESIMPULAN DAN SARAN}

Berdasarkan data dan pembahasan dapat diambil kesimpulan : Pertumbuhan dan produksi tanaman tomat terbaik dijumpai pada kombinasi perlakuan dosis pupuk guano 12 ton $\mathrm{ha}^{-1}$ dengan NPK $250 \mathrm{~kg} \mathrm{ha}^{-1}$.

\section{DAFTAR PUSTAKA}

Banuwa, I. S., M. A. Pulung dan M. Utomo. 2003. Pengaruh pemberian sisor (night soil) terhadap serapan NPK dan hasil tanaman jagung (Zea mays L.). Jurnal Tanah Trop. 16: 111-113.

Djuniwati, S., A. Hartono dan L.T. Indriyati. 2003. Pengaruh bahan organik (Pueraria javanica) dan fosfat alam terhadap pertumbuhan dan serapan $\mathrm{P}$ tanaman jagung (Zea Mays L.) pada andisol pasir sarongge. Jurnal Tanah dan Lingkungan, 5: 16-22.

Fuadi, J. 2016. Pengaruh dosis kompos limbah bubuk kopi dan NPK terhadap pertumbuhan dan hasil tanaman cabai merah (Capsicum annum L.). Fakultas pertanian. Universitas Syiah Kuala. Banda Aceh.

Hendri, M., M, Napitupulu., A, P, Sujalu. 2015. Pengaruh pupuk kandang dan pupuk npk mutiara terhadap pertumbuhan dan hasil tanaman terung ungu (Solanum Melongena L.). Jurnal Agrifor. 14(2): 1412-6885.

Kallie, M. B. 1993. Mengatasi buah rontok, busuk, dan berulat. Penebar Swadaya. Jakarta.

Lakitan, B. 2007. Dasar- dasar fisiologi tumbuhan. Raja Grafindo Persada. Jakarta.

Licardo, A. 2016, "Pupuk guano kotoran kelelawar", (http://guanogunungkidul.blogspot.co.id/2016/11/pupuk-guano.html). (Diakses pada tanggal 26 Maret 2017).

Lingga. P dan Marsono. 2004. Petunjuk penggunaan pupuk. Penebar Swadaya. Jakarta.

Maryanto dan A. Rahmi. 2015. Pengaruh jenis dan dosis pupuk organik terhadap pertumbuhan dan hasil tanaman tomat (Lycopersicum esculentum Mill) varietas permata”. Jurnal Agrifor. 14 (1), 88-89.

Putri, S.L. 2016. Pengaruh pemberian pupuk NPK dan pupuk hayati terhadap pertumbuhan dan produksi tanaman sedap malam (Polianthes tuberosa L.). Fakultas Pertanian Universitas Bandar Lampung.

Rachman, I. A., S. Djuniwati dan K. Idris. 2008. Pengaruh bahan organik dan pupuk NPK terhadap serapan hara dan produksi jagung di inceptisol ternate. Jurnal Tanah dan Lingkungan, 10 (1) : 1410-7333.

Rubatzky, V. E., dan M. Yamaguchi. 1999. Sayuran dunia 3. Institut Teknologi Bandung, Bandung.

Saberan. N, A. Rahmi, H. Syahfari. 2014. Pengaruh pupuk NPK pelangi dan pupuk daun grow $\mathrm{M}$ terhadap pertumbuhan dan hasil tanaman tomat (Lycopersicum esculentum Mill.) varietas permata. Jurnal Agrifor. 8(1): 1412-6885.

Sarawa., A. Nurmas., Dan M. Dasril. AJ. 2012. Pertumbuhan dan produksi tanaman kedelai (Glycine max L.) yang diberi pupuk guano dan mulsa alang-alang. 2 (2) : 97-105.

Sufardi. 2012. Pengantar nutrisi tanaman. Bina Nanggroe. Banda Aceh.

Sulkarnain. 1990. Devinisi mulsa dan perlakuan . Kanisius. Yokyakarta.

Suwarno dan K, Idris. 2007. Potensi dan kegunaan penggunaan pupuk guano secara lansung sebagai pupuk di Indonesia. Jurnal Tanah dan Lingkungan. 9(1):37-43.

Wawan. I, A. Wahyudi, dan C. Suherman, 2006. Pengaruh pupuk organik terhadap pasil kedelai (Glicine $\max$ (L.) Merr) dalam Sistem Tumpangsari dengan Sorghum (Shorghum bicolor L.) di Jatinangor. http://w.w.w.lppm.unpad.ac.id/archives/3270. 
Wiryanta. W. T. B. 2004. Bertanam tomat. Agromedia Pustaka. Jakarta.

Wudianto. R. 2001. Petunjuk penggunaan pestisida. Penebar Swadaya. Jakarta.

Yulipriyanto, H. 2010. Biologi tanah dan strategi pengelolaannya. Graha Ilmu. Yogyakarta. 